\title{
Economic Growth as Mediation of Regional Own Source Revenue, Investment and Asset Management on Labor Absorption and Social Welfare in Regencies/Cities in Riau Islands Province
}

\author{
Jontro Simanjuntak $^{1}$, Tri Ratnawati ${ }^{2} \&$ Nekky Rahmiyati $^{2}$ \\ ${ }^{1}$ Faculty of Economics, Putera Batam University, Indonesia \\ ${ }^{2}$ Faculty of Economics, University of 17 Agustus 1945 Surabaya, Indonesia \\ Correspondence: Priyono, Graduate Master of Management Program of Universitas Bina Darma, Palembang, \\ Indonesia. Tel: 62-812-1697-4878. E-mail: priyono.unu_sidoarjo@yahoo.com
}

Received: June 2, 2017

Accepted: June 21, 2017

Online Published: July 10, 2017

doi:10.5539/ijef.v9n8p127

URL: https://doi.org/10.5539/ijef.v9n8p127

\begin{abstract}
This study, entitled Economic Growth as Mediation of Regional Own-source Revenue, Investment and Asset Management on the Labor absorption and Social welfare of Regencies/City in Riau Islands province. This study was conducted at the district / city located in the province of Riau Islands. There are Exogenous constructs (X) namely income, investment, and asset management variables. There are Intermediate variables (Y) namely economic growth and labor absorption. There is an endogenous construct namely social welfare. There are 12 hypotheses tested by using path analysis or SmartPLS.

The results in this study show that the $1^{\text {st }}$ hypothesis as the regional Own-source Revenue has a significant effect on economic growth. Hypothesis 2 Regional Own-source Revenue has a significant effect on labor absorption. Hypothesis 3 Regional Own-source Revenue significantly influence the social welfare. Hypothesis 4 Investment has significant effect on economic growth. Hypothesis 5 Investment has non-significant effect on labor absorption. Hypothesis 6 Investments significant effect on the social welfare. Hypothesis 7 Asset Management has non-significant effect on economic growth. Hypothesis 8 Asset Management has a significant effect on labor absorption. Hypothesis 9 Asset Management has significant effect on the social welfare. Hypothesis 10 Economic growth has non-significant effect on labor absorption. Hypothesis 11 The economic growth has significant effect on the social welfare. Hypothesis 12 Labor absorption has significant effect on the social welfare.
\end{abstract}

Keywords: economic growth, regional own-source revenue, investments, asset management, labor absorption, social welfare

\section{Introduction}

Indonesia's national five year development plan stipulated in the National Medium Term Development Plan (RPJMN) 2015-2019 is necessary for prioritizing in order to achieve food sovereignty, energy sufficiency and maritime and marine resources management. The five year development plan should increasingly lead to sustainable improved welfare conditions. The social welfare improvement as a barometer of success can be seen from the quality of the Human Development Index (HDI) including life expectancy, literacy rates, average length of school and average per capita income.

Based on BPS data of Riau Islands Province in 2015 the Human Development Index in 2013 was 69.97\%, this was still below the national standard. The government of Riau islands Province has a program to improve social welfare. The program leads to the formation of special department-level agency in charge of coastal areas in order to avoid a gap between the public on the main island (Batam). The program consists of installation of solar power flow to meet the electricity needs by coastal communities, early childhood education program to spur one village, an early childhood education and family empowerment program for economic improvement.

Labor is every person having capability to conduct any work both within and outside the labor absorption relationship in order to produce goods and services to meet the community needs. Labor or the so-called Working Age Population (PUK) consists of labor force and not labor force. Proper labor absorption means that 
there will be improvement on fulfillment on the physical and spiritual needs. Riau Islands Province, based on the 2013 data, the labor absorption reached nearly $93.74 \%$ of the workforce.

Economic growth is a process of change in a country economic sustainability leading to a better condition for a certain period. The economic growth is an indication of the economic development success because the economic growth is associated with the increase on production capacity that is realized in the form of the increase on national income. Riau Islands Province in 2015 had the economic growth rate by $7.14 \%$ occurred in all sectors of the business field.

Local revenue is the revenue from local sources of revenue consisting of local taxes and levies. Riau Islands Province has source of income that is still dominated by Balance Fund. The average Local Revenue (PAD) proportion is still below namely $40 \%$ of the revenues derived from local taxes, levies and other lawful income.

Investment is related to the accumulation of assets with an expectation to obtain profit in the future. The investments consist of three types, namely government investment, domestic investment and foreign investment. An area having most large investment level is an area with high infrastructure, natural resources and human resources. The Regency/City with higher investment level is city Batam because it has good level of infrastructure and very strategic to other countries.

Asset management is a combination of management, finance, economics, engineering machinery and working practices applied to the physical assets. This aims to possess the ability to provide the level of excellent service in the most cost efficient. Proper local asset management can increase social welfare because its function is bigger. There is lack of asset management in Riau Islands province, this can be seen from current unclear status of land and many regional assets that are not used by the regional Government. Many local assets are controlled by individual / private business.

Based on the above issues, there is a gap among the Human Development Index in Riau Islands Province. This is still far from the human development index in the national/international standards which is minimum by $80 \%$. It means that Riau Islands province is still far from welfare. Excellent labor absorption is $93 \%$ of the total work force. Sources of Economic Growth in the districts/cities are quite high and the investment in the area has not been evenly distributed and the asset management in the areas is still far from the expectations because it still has relatively enough and less healthy. This means that there is a problem between regional revenue (PAD), Investment and Asset Management on the Economic Growth, Absorption of Labor and Social welfare.

The purpose of this study is to prove and analyze the effects of income, investment, and asset management on the economic growth, labor absorption and social welfare in the Regency / City in Riau Islands province.

\section{Literature Study}

\subsection{Economic Development}

Economic development is a country economy with its initial more or less static economic condition in long enough period so that it can create and maintain the increase in the gross national income or income per capita (Todaro, 2006, p. 22).

Regional economic development is a process in which local governments and communities process the existing natural resources and form a pattern of partnership between local governments and private sectors to create new jobs and development of economic activities in the region (Adisasmita, 2011, p. 20).

The principal issue in regional development is the emphasis on the development policies based on the area specificity in concerned, by using potency of human resources, institutional and local physical resources.

\subsection{Economic Growth}

Economic growth is a condition of potential development reflecting the GNP per capita output growth and increasing living standards. (Asfia Pure, 2006, p. 173). The economic growth is the increase in a country long-term capacity in concerned to provide a variety of economic goods for its citizens (Kuznets in Todaro, 2006, p. 99). The potential for a country economic growth is strongly influenced by quantity and quality of its resources, both physical resources or natural resources (in the form of fertile soil, content of valuable minerals, and other raw materials with economic value) and source of human resources, namely population and level of skills or education (Todaro, 2006, p. 49).

\subsection{Investment}

Investment basically is the current placement of funds with expectation to make profit in the future (Fahmi Abdul Halim in 2012, p. 2). According to the IAS 13 accounting standards October $1^{\text {st }}, 2004$, the investment is 
an asset to be used by companies for the accretion of wealth through distribution of investment returns (such as interest, royalties, dividends, and rents), to increase the investment value, or other benefits for companies giving their investment such as the benefits gained through trade relations.

\subsection{Regional Own Source Revenue}

Local revenue consists of tax and retribution (Widjaja, 2013, p. 78). Revenue is derived from local area revenues, the local revenue is derived from distribution of local revenue, financial balance between central government and local governments, regional loan, and other lawful incomes (Darwin, 2010, p. 67). Tax is a levy from the society taken as the state treasury by law (enforceable) with no returns received (contra) which can be directly used to pay for general expenses (Rochmat Soemitro in Adisasmita 2011, p. 95). Area retribution acceptance is obtained from private households based on general norms, associated with the achievement held by and for the benefit of society in particular it has been applied by public authorities (Goedhart, 1982; in Adisasmita, 2011, p. 108)

\subsection{Asset Management}

Asset management is a profession or skill that is not fully developed and popular in governmental environment or in work unit or institution. Regulation of Asset management No. 17 of the Year 2007 Article 4 paragraph 2 states that goods management areas include planning and budgeting, procurement, acceptance, storage and distribution, usage, administration, utilization, security and maintenance, assessment, removal, transfer, development, supervision and control, financing, and claim for compensation. The area assets are resources owned or controlled in an economical manner and can be measured in terms of money (Halim, 2004, p. 79),

\subsection{Labor Absorption}

Labor absorption is a certain amount of labor used within a business unit or number of people working in a business unit (Zamrowi, 2007), labor absorption is the number of labor demanded that is more addressed at the quantity or number of labor needs at certain wage level. So the labor absorption means as the labor absorption that has filled by large number of labor based on the labor quantity or the demand at certain wage level (Rejekiningsih, 2004). Labor absorption is influenced by several factors including level of wages and value of production (Suerna, 2012).

\subsection{Social Welfare}

Social welfare is an organized system of social services and institutions that aims to help individuals and groups to achieve living standard and satisfactory health and personal and social relations allowing to develop abilities as fully as possible and to improve the welfare well-adjusted to family and community needs. Social welfare is including human being actions to achieve society better level, while according to the formulation of the Acts of the Republic of Indonesia No. 6 of the year 1974 concerning the basic provisions of social welfare in Article 2, paragraph 1, it states that: "social welfare is a order of life and livelihood of social, material and spiritual life covered by a sense of safety, decency and peace outwardly and inwardly, allowing every citizen to hold fulfillment of physical, spiritual and social needs as well as possible for themselves, their families and communities by upholding the rights and obligations according to Pancasila ".

\subsection{Accomplishment Research}

Achmad Daeng (2014) conducted a research on the effects of private investment, government investment, on economic growth and labor absorption and social welfare in the Regency / City in East Java province. The research stated that private investment and government investment have significant effects on economic growth and labor absorption as well as social welfare and then the labor absorption affected on the social welfare.

Sitorus (2013) examined the effects of capital expenditure and revenue (PAD) on the economic growth in Kalimantan. The results showed that simultaneously capital expenditure and revenue (PAD) have significant effects on the economic growth in Kalimantan. Partially, income has positive effects on the economic growth in Kalimantan

Bagus Suryono (2007) examined the Influence of an Analysis on Regional Income, Investment and Labour on the GDP of Central Java. The results showed that PAD, Level of Investment, Labor have positive and significant effects partially or simultaneously on the GDP of Central Java.

Mawardi (2004) conducted a research concerning the effects of West Java Government investment on the labor absorption in Jakarta, West Java and others. Based on the relatedness value of front and fore values, it can be concluded that there are positive and significant effects of the West Java government policy towards small industry, paper industry and metal goods sectors in West Java province but the effects are less meaningful to Jakarta and other areas. Most sectors in the province of West Java and other Regional have economic linkages, 
in comparison to similar other sectors in Jakarta.

Priyagus (2007) conducted a research concerning the effects of private investment, labor and development spending on the economic growth and welfare in East Kalimantan province, with the results showing that private investment has direct, positive and significant effects on the economic growth; number of workers has no significant effect on the economic growth; development expenditure has no significant effects on the economic growth; private investment has indirect, positive and significant effects on the social welfare; number of labor has no significant effects on the social welfare; development expenditure has direct, positive and significant effects on the social welfare and the economic growth has direct, positive and significant effects on the social welfare.

Wijayanti (2015) examined the effects of Regional Income and General Allocation Fund on the Social welfare Through the Economic Growth (a Study on regencies / cities in Bali Province in the Period of 2008-2013). The results showed that sources of revenue and general allocation funds have significant and positive effects on the economic growth, local revenue and general allocation fund.

Based on the above description of the hypothesis formation, it can be made the research conceptual framework as follows:

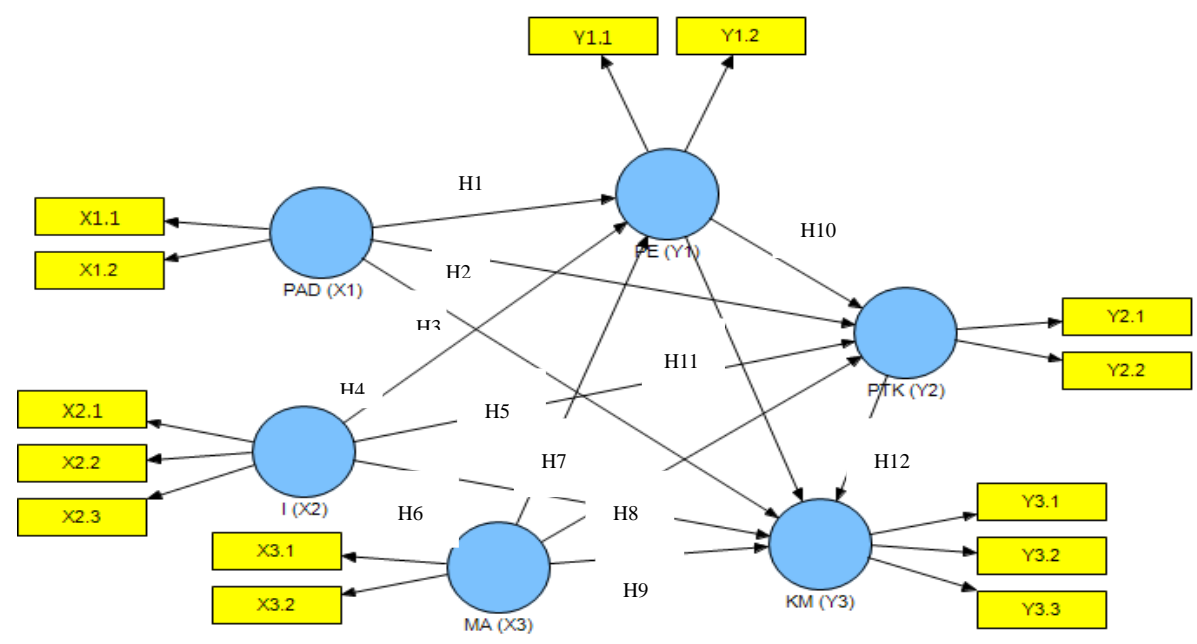

Figure 1. Conceptual framework

Based on the formulated background problem, the literature review and conceptual framework, the proposed research hypotheses are as follows:

H1: source of revenue has significant effects on the economic growth in Riau Islands province.

$\mathrm{H} 2$ : source of revenue has significant effects on the labor absorption in Riau Islands province.

H3: source of revenue has significant effects on the social welfare in Riau Islands province.

H4: Investment has significant effect on the economic growth in Riau Islands province.

H5: Investment has significant effect on the labor absorption in Riau Islands province.

H6: Investment has significant effects on the social welfare in Riau Islands.

H7: Asset Management has significant effects on the economic growth in Riau Islands province.

H8: Asset Management has significant effect on the labor absorption in Riau Islands province.

H9: Asset Management has significant effect on the social welfare in Riau Islands province.

H10: Economic Growth has significant effect on the labor absorption in Riau Islands province.

H11: Economic Growth has significant effect on the social welfare in Riau Islands province.

H12: labor absorption has significant effect on the social welfare in Riau Islands province.

\section{Research Methods}

\subsection{Research Design}

This study is a type of conclusive research and an explanatory research as well as hypothesis testing. That is, the 
research is addressed to clarify the effects among the variables or causal relationships between the variables through the hypothesis testing (Noor, 2011, p. 110).

\subsection{Population and Sample}

The study population is limited and relatively in small population size namely 7 Regencies / City, then in this study, it was using census method, namely Karimun, Bintan district, Natuna Regency, Lingga Regency, Anambas Island, City of Batam and Tanjung Pinang. The data used in this study is a combination of secondary data in the form of coherent data and cross-refer data called as the panel data covering the period 2010-2015.

\subsection{Operational Research Variable}

The operational research variable is an explanation of each variable used in the study as the indicators to make it up. The operational variables can be explained by the following table:

Table 1. Research variable

\begin{tabular}{|c|c|c|}
\hline Construction Variables & Notation & Manifest Variables (indicators) \\
\hline \multirow[t]{2}{*}{ 1. Own-source revenue } & $\mathrm{X} 1$ & 1.1. Tax $(\mathrm{X} 1.1)$ \\
\hline & & 1.2. Restribution (X1.2) \\
\hline \multirow[t]{3}{*}{ 2. Investments } & $\mathrm{X} 2$ & 2.1 Foreign Investment $(\mathrm{X} 2.1)$ \\
\hline & & 2.2 Domestic investment $(\mathrm{X} 2.2)$ \\
\hline & & 2.3 Government investment (X2.3) \\
\hline \multirow[t]{2}{*}{ 3. Asset Management } & $\mathrm{X} 3$ & 3.1 separated Results of Intellectual Management (X3.1) \\
\hline & & 3.2 other legalized PAD (X3.2) \\
\hline \multirow[t]{2}{*}{ 4. Economic growth } & Y1 & 4.1 Current Price (Y1.1) \\
\hline & & 4.2 Constant Price (Y1.2) \\
\hline \multirow[t]{2}{*}{ 5. labor absorption } & $\mathrm{Y} 2$ & 5.1 Labor Force (Y2.1) \\
\hline & & 5.2 Not labor force (Y2.2) \\
\hline \multirow[t]{3}{*}{ 6. SocietyWelfare } & Y3 & 6.1 Life Expectancy (Y3.1) \\
\hline & & 6.2 Average Old School (Y3.2) \\
\hline & & 6.3 Expenditure Per Capita (Y3.3) \\
\hline
\end{tabular}

Source: Processed Researcher.

\section{Results and Discussion}

\subsection{Analysis and Research}

\subsubsection{Outer Evaluation Model}

Outer Model specifies the relationship between the variables studied with its indicators.

\subsubsection{Convergent Validity}

Each indicator in the model should meet the convergent validity, which has a value of $>0.5$. If any indicator has been complied with, the evaluation step can proceed. But if not, it should conduct reduction on the indicators with convergent validity value $<0.5$ by doing further literacy until it is obtained loading factor values by $>0.5$. So, to find out whether regional own source revenues, Investments, Asset Management, Economic Growth, Absorption of Labor, and Social welfare are latent variables, it is used confirmatory factor analysis with the results with SmartPLS program can be seen in Figure 2. 


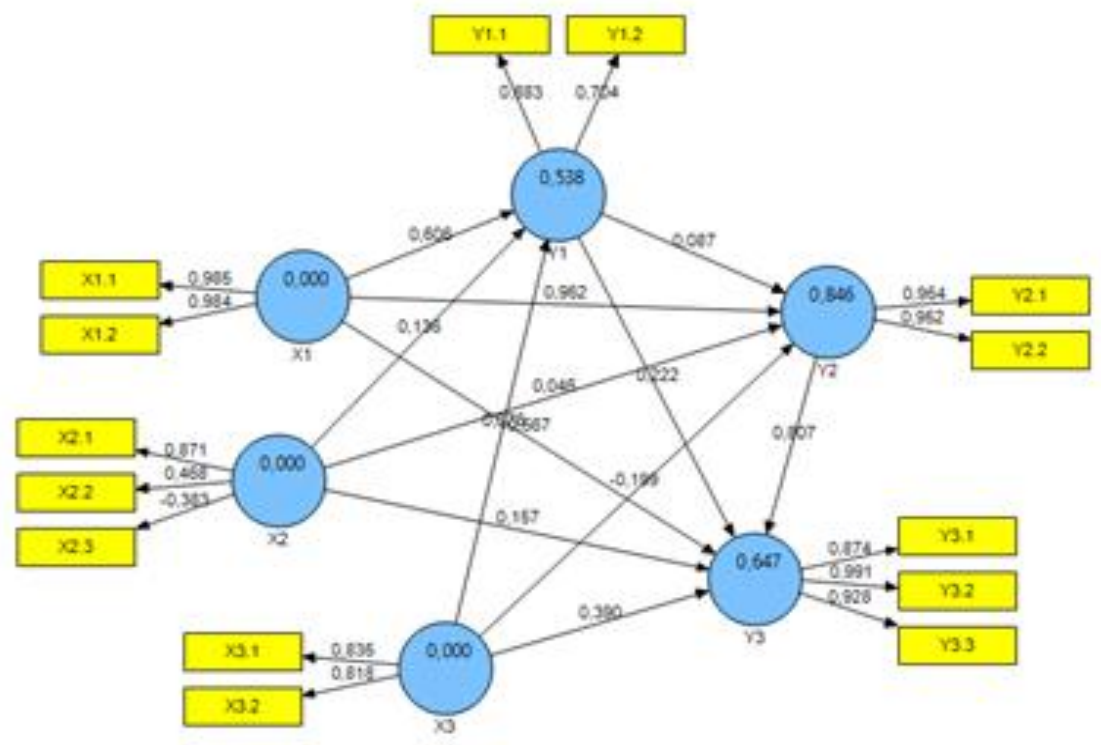

Figure 2. Test results of factor loading model

Based on Figure 2, it shows that not every indicator has loading factor value by $>0.5$ meaning that not all the indicators are considered valid to be the indicator variable. Based on that, the loading values are 0.468 and 0.383 for domestic investment (X2.2) and government investment (X2.3) which is less than 0.5, which that means the domestic investment (X2.2) and government investment (X2.3) indicators should be reduced in measuring the investment (X2) as shown below:

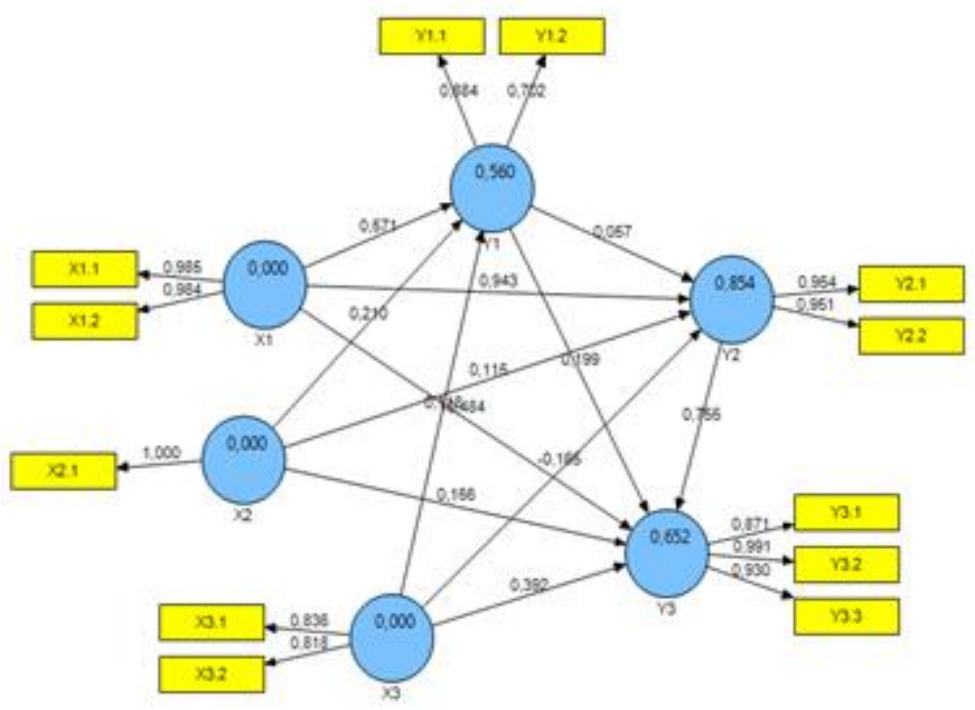

Figure 3. Test results of factor loading models after reduction

\subsubsection{Discriminant Validity}

Discriminator validity test aims to test on the validity of block indicators. The discriminator validity test on the indicators can be seen in cross loadings between indicators and construct, if the value of each indicator in measuring its construct variables is predominantly higher than the respective values its indicators in measuring other construct variables. Each indicator variable has high convergent construct validity value, namely more than 0.5. This means that all indicators used in this study are valid to measure each construct variable. 


\subsubsection{Composite Reliability}

Composite reliability of block indicators measuring the construct studies meet the composite reliability criteria, so that each construct is able to be positioned as the research variables.

Table 3. Composite reliability

\begin{tabular}{lc}
\hline Construct & Composite reability \\
\hline regional own source revenue(X1) & 0,984 \\
Investment (X2) & 1,000 \\
Asset Management (X3) & 0,812 \\
economic growth (Y1) & 0,776 \\
Labor absorption (Y2) & 0,952 \\
social welfare (Y3) & 0,952 \\
\hline
\end{tabular}

Source: Processing Data, 2017.

Based on Table 3 it shows that all composite reliability variables have values by $>0.6$ then all variables have adequate internal consistency in measuring the latent variables / measured constructs.

\subsubsection{Average Variance Extracted (AVE)}

AVE aims to test the reliability of construct variables, the AVE value is declared to be satisfactory if it is $>0.5$. AVE test results can be in Table 4 as follows:

Table 4. AVE values

\begin{tabular}{ll}
\hline Construct & AVE \\
\hline regional own source revenue(X1) & 0,984 \\
Investment (X2) & 1,000 \\
Assets Management (X3) & 0,684 \\
economic growth (Y1) & 0,637 \\
Labor absorption (Y2) & 0,908 \\
Social welfare (Y3) & 0,868 \\
\hline
\end{tabular}

Source: Data Processing, 2017.

Based on Table 4, it shows that the AVE results on the block indicator measuring on the construct can be stated to have good validity discriminat values. This means that all construct variables are declared to be reliable.

\subsection{Hypothesis Testing}

To answer the hypothesis research, t-statistic can be seen in Table 5 below:

Table 5. Table inter construct

\begin{tabular}{llll}
\hline The results of path analysis & Original sampel estimate & T statistic & Information \\
\hline regional own source revenue $(\mathrm{X} 1) \rightarrow$ economic growth $(\mathrm{Y} 1)$ & 0,571 & 4,427 & Significant \\
regional own source revenue $(\mathrm{X} 1) \rightarrow$ labor absorption $(\mathrm{Y} 2)$ & 0,943 & 12,426 & Significant \\
regional own source revenue $(\mathrm{X} 1) \rightarrow$ social welfare (Y3) & 0,118 & 2,928 & Significant \\
Investment $(\mathrm{X} 2) \rightarrow$ economic growth (Y1) & 0,210 & 3,747 & Significant \\
Investment $(\mathrm{X} 2) \rightarrow$ labor absorption $(\mathrm{Y} 2)$ & 0,115 & 1,416 & Not Significant \\
Investment $(\mathrm{X} 2) \rightarrow$ social welfare $(\mathrm{Y} 3)$ & 0,166 & 2,329 & Significant \\
Assets Management $(\mathrm{X} 3) \rightarrow$ economic growth $(\mathrm{Y} 1)$ & 0,484 & 0,886 & Not Significant \\
Assets Management $(\mathrm{X} 3) \rightarrow$ labor absorption $(\mathrm{Y} 2)$ & $-0,165$ & 2,048 & Significant \\
Assets Management $(\mathrm{X} 3) \rightarrow$ social welfare (Y3) & 0,392 & 2,928 & Significant \\
economic growth $(\mathrm{Y} 1) \rightarrow$ labor absorption (Y2) & 0,057 & 0,995 & Not Significant \\
economic growth $(\mathrm{Y} 1) \rightarrow$ social welfare $(\mathrm{Y} 3)$ & 0,199 & 3,555 & Significant \\
labor absorption $(\mathrm{Y} 2) \rightarrow$ social welfare $(\mathrm{Y} 3)$ & 0,755 & 3,509 & Significant \\
\hline
\end{tabular}

Source: processing Data, 2017.

\subsubsection{Effects of Regional Own Source Revenue on the Economic Growth}

Based on the results of path analysis in Table 5, it shows that the result of the value of regional revenue of $t$ 
statistic value is 4.427 which is greater than 1.96 , meaning that regional revenue has significant effects on the economic growth. The results support researches by Sitorus (2013), Wiratno (2007) and Emalia (2014).

The large increase on regional revenues can simply increase the economic growth in this area to support government programs by providing regional authority to manage / explore sources of finances in the region. Regional development is an integral part of national development, then in this case, it is necessary for financial funds for the development expenditure.

\subsubsection{Effects of Regional Own Source Revenue on the Labor Absorption}

Based on the results of path analysis in Table 5, it shows that $\mathrm{t}$ statistic value is 12.426 which is greater than 1.96 , meaning that regional own source revenue has significant effects on the labor absorption. The results of this study are contrary to researches Azran (2007) and Elmalia \& Sri (2014) with results of research stating that acceptance on coal mining royalty has no effect on the labor absorbtion.

Riau Islands Province is a province with relatively young age, it was established in 2002 desperately requiring huge funds for the labor absorption through regional development. The increase on the development will absorb more manpower, it takes a very high financial by optimizing regional own source revenue.

\subsubsection{Effects of Regional Own Source Revenue on the Social Welfare}

Based on the results of path analysis in table 5, it shows that the $t$ statistic values is 2.928 which is greater than 1.96 , meaning that regional own source revenue has significant effects on the social welfare. The results of this study are contrary to a research by Azran (2007) stating the results of research that the acceptance coal mining royalty do not affect on the social welfare. Local Government of Riau Islands Province encourages on the increase of regional own source revenues to improve the social welfare sourced from tourism, industry and trade sectors.

\subsubsection{Effects of Investments on the Economic Growth}

Based on the results of path analysis in Table 5, it shows that the t statistic value is 3.747 greater than 1.96 meaning that the investment has significant effects on the economic growth. This is consistent with researches by Mulyadi (2005), Priyagus (2007), and Ahmad (2014) showing that the investment both private and public investments has significant effects on the economic growth. one source of effects of the economic growth is from the investment by encouraging high investment so that there will be high economic growth in Riau Islands province. The Investments in Riau Islands province consist of government investment and domestic investment. Most districts / cities in Riau Islands Province are free trade zone (FTZ) such as Batam, Karimun and Bintan regencies, in these FTZ areas, there are many foreign investments.

\subsubsection{Effects of Investment on the Labor Absorption}

Based on the results of path analysis in Table 5 it shows that $t$ statistic value is 1.416 which is smaller than 1.96 , meaning that investment has insignificant effect on the labor absorption. This research differs from a research by Nekky (2008) stating that there is effect of the investment on the labor absorption. Investments are mostly in manufacturing, trade and tourism sector. In the sector, there is large labor absorption. Riau Islands Province is an archipelagic region and relatively young province as established in 2002, it has no all districts / areas at its establishment. The investment is not evenly distributed. The most attractive regencies / cities are Batam, Bintan and Karimun regency.

\subsubsection{Effects of Investment on the Social Welfare}

Based on the results of path analysis in Table 5, it shows that the t statistic value is 2,329 which is greater than 1.96 meaning that the Investment has significant effect on the social welfare. The research supports a research by Nekky (2008) stating that there is effects of the investment on the labor absorption.

\subsubsection{Asset Management on Economic Growth}

Based on the results of path analysis in Table 5, it shows that the $t$ statistic value is 0.886 which is smaller than 1.96, meaning that Asset Management has no significant effect on the economic growth. Proper asset management will lead to considerable benefits. There is lack of asset management in Riau Islands Province as can be seen from unclear status of land assets because Riau Islands province is a division of Riau province. Maritime tourism area is many managed and privately owned for business, so that it does not give revenue directly to the local governments. The local government with excellent asset management is Batam city because the area is managed by the Batam Authority or currently called as Batam Entrepreneur Board (BP Batam). 


\subsubsection{Asset Management on Labor Absorption}

Based on the results of path analysis in Table 5 it shows that the $t$ statistic value is 2.048 which is greater than 1.96, meaning that the Asset Management has significant effects on the labor absorption.

\subsubsection{Asset Management on Social Welfare}

Based on the results of path analysis in Table 5 it shows that the $t$ statistic value is 2,928 which is greater than 1.96, meaning that the Asset Management has significant effects on the social welfare.

\subsubsection{Economic Growth on Labor Absorption}

Based on the results of path analysis in Table 5 it shows that the $t$ statistic value is 0.995 which is smaller than 1.96 , meaning that the economic growth has no significant effect on the labor absorption. This study has different results with researches by Nekky (2008), Ahmad (2015), Elmalia \& Sri (2014) and Sobita (2014) stating that the Economic Growth has significant effects on Labor Absorption. This study supports a research by Azran (2007) stating that regional economic growth has no effect on the labor absorption.

\subsubsection{Economic Growth on the Social Welfare}

Based on the results of path analysis in Table 5 it shows that the $t$ statistic value is 3.555 , which is greater than 1.96 meaning that the economic growth has significant effects on the social welfare. This research differs from a research by Azran (2007) stating that the regional economic growth has no significant effect on the social welfare. This study supports researches by Priyagus (2007), Elmalia \& Sri (2014) and Ahmad (2015) stating that the economic growth has positive and significant and direct effects on the social welfare.

\subsubsection{Labor Absorption on Social Welfare}

Based on the results of path analysis in Table 5 it shows that the $t$ statistic value is 3.509 which is greater than 1.96 meaning that the Labor Absorption has significant effects on the social welfare. This study supports researches by Elmalia \& Sri (2014), Nekky (2008) Achmad (2015) stating that labor Absorption has significant effects on the social welfare.

\section{Conclusions and Suggestions}

Based on the problem formulation and analysis that have been described previously, it can deliver some conclusions and suggestions as follows:

\subsection{Conclusions}

1) The regional own-source revenue has effects on the economic growth, labor absorption and social welfare. This result is consistent to results based on Widjaja theory, (2013). The research results are similar to results of researches by Sitorus (2013), Wiratno (2007) and Emalia (2014). The results of this study are different to results of researches by Azran (2007) and Elmalia \& Sri (2014). The results of this study are different to a research by Azran (2007).

2) Investments have effects on the economic growth and social welfare. The results of this research are in line with researches by Mulyadi (2005), Priyagus (2007), and Ahmad (2014). This research results are in line with a research by Nekky (2008).

3) The investment has no effect on the labor absorption. The results of this study are different to a research by Nekky (2008).

4) The Asset management has no effect on the economic growth

5) The Asset management has significant effects on the labor absorption and social welfare

6) The economic growth has no significant effect on the labor absorption. The results of this study are different to results of researches by Nekky (2008), Ahmad (2015), Elmalia \& Sri (2014) and Sobita (2014) but in line with a Research by Azran (2007)

7) The Economic growth has significant effect on the social welfare. The results of this study are different to a research by Azran (2007) but in line with researches by Priyagus (2007), Elmalia \& Sri (2014) and Ahmad (2015).

8) The labor absorption has significant effects on the social welfare. This research result is in line with researches by Elmalia \& Sri (2014), Nekky (2008) Achmad (2015).

\subsection{Suggestions}

The conclusions as described in the previous section provide information for the researchers to give the 
following suggestions:

1) For Local Government of regencies / Cities in Riau Islands Province, it should increase its regional own source revenue even further because total of regional own source revenues serves to the social welfare. But partially, the labor absorption is the key in improving the social welfare.

2) For Local Government of regencies / Cities in Riau Islands Province, it should improve the implementation of asset management so that it can be better as expected, especially in outer islands in order to improve the social welfare.

3) For researchers who want to examine the same issue, they should add empirical evidences as well as enrich indicators so that there will be refine model of research.

\section{References}

Adisasmita, \& Rahardjo. (2011). The Regional Revenue Management \& Budget. Yogyakarta: Graha Science.

Anonymous. (2009). The Public Sector Accounting. Yogyakarta: Andi.

Anonymous. (2011). Regional Development Funding. Yogyakarta: Graha Science.

Daeng, \& Achmad. (2014). The effect of private investment, government investment to economic growth and labor absorption and social welfare districts / cities in East Java province. Dissertation, Faculty of Economics, University August 17 Surabaya.

Dornbusch, R., Stanley F., \& Richard, S. (2008). Macro Economics. Jakarta: PT Media Global Education.

Elmalia, T., \& Sri, K. (2014). The Influence of Regional Revenue towards Economic Growth, Labor absorption and Social welfare in Palangkaraya, Central Kalimantan Province. European Journal of Business and Management, 6(8).

Ferdinand, \& Auguty. (2014). Management Research Methodology. Agency Diponegoro University Semarang.

Halim, \& Abdul. (2004). The Regional Financial Accounting. Jakarta: Salemba Four.

Jaya, I. P. N. F. K., \& Dwirandra, A. A. N. B. (2014). The Local Revenue Effect On Growth Capital Expenditures For the moderating variables. Journal of Accounting.

Joseph, M. (2010). Step Asset Management, Financial Management Towards best. Jakarta: Salemba Four.

Mankiw, N. G. (2006). Introduction to Macro Economics (3rd ed.). Jakarta: Salemba Four.

Mardiasmo. (2009). Autonomy and Regional Financial Management of good governance. Yogyakarta: Andi.

Noor, \& Juliansyah. (2011). Research methodology thesis, dissertations and scientific papers. Jakarta: Kencana Prenadamedia Group.

PP No. 58. (2005). On Regional Financial Management.

Rini, \& Sulistiawati. (2012). Effects of Minimum Wages on Labor Absorption and Public Welfare in the province in Indonesia. The Economic and Social Journal, 8(3).

Samuelson, P. A., \& William, D. N. (1992). Macroeconomics (14th ed.). Editor Yati Sumiharti. The McGraw-Hill Companies, Inc.

Sanusi, \& Anwar. (2012). The Business Research Methodology. Jakarta: Salemba Four.

Sastrosoenarto, Hartanto 2006, industrialization well as the Agricultural Development and Services Towards Vision 2030 Mission Indonesia. Publisher Gramedia Pustaka Utama: Jakarta.

Setiawan, \& Hendra, A. (2010). Analysis of labor absorption in the sector of small and medium enterprises (SMEs) in the city of Semarang. Retrieved from http://ep.unnes.ac.id/wp-content/uploads/2012/03/04-Achma-Hendra-Setiawan.pdf

Sitorus. (2013). Effect of capital expenditure and revenue (PAD) to economic growth in the region of Borneo.

Sobita, \& I Wayan, E. N. S. (2014). Economic Growth and Labor Absorption. Journal of Development Economics, 3(2).

Soemarso, S. R. (2007). Taxation, Comprehensive Approach. Jakarta: Salemba Four.

Sukirno, \& Sadono. (2006). Micro Economic Theory Introduction (3rd ed.). Jakarta: PT RajaGrafindo Persada.

Suryono, N. (n. d.). Analysis Effect of PAD, Level Investment, and Labor Against Central Java GRDP . Faculty of Economics, University of Diponegoro. Journal of Development Economics, 61-70. 
Tangke, J. G., Halim, H., \& Gina, L. (2015). Effect of Regional Asset Management Optimizing the Quality of Makassar City Government Financial Report. Journal of Public Administration.

Todaro, M. P., \& Stephen, C. S. (2006). The Economic Development in the Third World (8th ed.).

Waisgrais, \& Sebastian. (2003). Wage Inequality And The Labor Market In Argentina: Labor Institutions, Supplyand Demand In The Period 1980-99 (pp. 1-53). International Institute for Labor Studies Discussion Paper.DP / 146/2003, Decent Work Research Program.

Wibi, H. (2006). Macroeconomics (6th ed.).

Widjaja, \& Haw. (2013). Implementation of Autonomy in Indonesia in the socialization of LawNo. 32 of 2004 on local government. Jakarta: PT RajaGrafindo Persada.

Wijayanti, N. K. H., \& Ida, B. D. (2015). E-Journal of Economic Development Udayana University, 4(9).

Wiyono, \& Gendro. (2011). Designing Business Research with SPSS \& SmartPLS justice. Yogyakarta: UPP STIM YKPN.

Zamrowi, M. T. (2007). Labor Absorption Analysis on Small Industries (Study in Small Industries Furniture in Semarang. Diponegoro University in Semarang.

\section{Copyrights}

Copyright for this article is retained by the author(s), with first publication rights granted to the journal.

This is an open-access article distributed under the terms and conditions of the Creative Commons Attribution license (http://creativecommons.org/licenses/by/4.0/). 